\title{
Article
}

\section{Planning for climate change impacts: coastal tourism destination resilience policies}

Jarratt, David

Available at http://clok.uclan.ac.uk/29797/

Jarratt, David ORCID: 0000-0002-7244-428X (2020) Planning for climate change impacts: coastal tourism destination resilience policies. Tourism Planning \& Development, 17 (4). pp. 423-440. ISSN 2156-8316

It is advisable to refer to the publisher's version if you intend to cite from the work. http://dx.doi.org/10.1080/21568316.2019.1667861

For more information about UCLan's research in this area go to http://www.uclan.ac.uk/researchgroups/ and search for < name of research Group>.

For information about Research generally at UCLan please go to http://www.uclan.ac.uk/research/

All outputs in CLoK are protected by Intellectual Property Rights law, including Copyright law. Copyright, IPR and Moral Rights for the works on this site are retained by the individual authors and/or other copyright owners. Terms and conditions for use of this material are defined in the policies page.

\section{CLoK}

Central Lancashire online Knowledge www.clok.uclan.ac.uk 


\title{
Planning for climate change impacts: coastal tourism destination resilience policies.
}

\begin{abstract}
Coastal tourism is a vital part of the world economy bit also facilitates access to 'blue spaces' - this offers significant health benefits to populations and shapes our relationship with the coast. At present, climate change impacts on the coast, such as storm surges and rising sea levels, are an inevitability and, in some regions, they are already damaging coastal tourism economies. It is clear, therefore, that our relationship with the coast will change. Given the importance of coastal tourism, this new relationship needs to incorporate adaptive measures; including a blue space and wellbeing focus, education and awareness of challenges facing the natural environment. We make this case by re-evaluating the literature on coastal tourism and climate adaptation policies. Using recent examples, we also offer an indication of new policy directions for coastal destinations. At present coastal tourism plans and policies largely ignore how destinations might respond and adapt to climate change impacts. We critique this and suggest that the human-environment relationship should be placed directly at the centre of all thinking on this topic.
\end{abstract}

\section{Key Words}

Climate Change; Global Warming; Coastal Tourism; Resilience; Adaptation; BlueSpace; Neo-Terraqueous.

\section{Introduction}

No form of leisure tourism is more significant in scale or economic value than coastal tourism. The United Nations estimates that "approximately half of tourists visit a coastal area" (UNWTO, 2013, p.8). The next few decades will see significantly greater impacts from extreme weather events, sea-level rises and flooding at coastal destinations, which will have major implications for tourism development. This article addresses competing narratives of, firstly, policies to increase coastal tourism and, 
secondly, those which address coping with the impacts of climate change. It critiques recent work in tourism study on mitigation and adaptation; two key policy strategies to manage risk from climate change. The value of this is to develop a discussion for much needed future empirical research, and more joined up and effective policy.

In the last decade increasing interest in the health benefits of exposure to coastal areas, has overlaid traditional valuations of the economic potential of tourism development. In addition to mitigation, adaptation and resilience, this article introduces additional dimensions which will be significant to future dialogue on coastal tourism research, in particular, 'blue spaces' (meaning aquatic environments such as the beaches or riversides; they are increasingly linked to human health/wellness). Central to the discussion are tourists and destinations, our relationship with the natural environment, and its co-evolution with the changing coast.

We begin with a rethink of the value of coastal tourism, including the arguments concerning blue-space and wellbeing, and follow this by a critical outline of current thinking on climate change adaptation. We then address the dichotomous circumstances which policy-makers and planners at coasts find themselves in, and finally, provide an appraisal of how the future direction of coastal tourism planning should be navigated and how our relationship with the coast will change.

This discussion will follow the definition of coastal tourism offered by Hall (2001, p.602),

The concept of coastal tourism embraces the full range of tourism, leisure, and recreationally oriented activities that take place in the coastal zone and the offshore coastal waters. These include coastal tourism development (accommodation, restaurants, food industry, and second homes), and the infrastructure supporting coastal development (e.g. retail businesses, marinas, and activity suppliers). 


\section{1) The value of coastal tourism - blue spaces and economies.}

\section{1) The economic impact of tourism and wellbeing at coasts}

The physical and social distinctiveness of the coast are bound have held several meanings and connotations through history, from fear to awe to nostalgia (Corbin 1995, p.13 \& p.53; Gillis 2012, p.117; Jarratt \& Gammon 2016). Associations between the coast with health restoration and wellness have evolved since industrialisation. Corbin (1995, p.62) and Gillis (2012 p.137) suggest that modern urbanites now seek to reconnect to an idealised version of the coast, from which they have become increasingly isolated over the last two or three hundred years. Gillis (2012, p.99) writes, "Our Ancestors did not make as sharp a distinction between land and water as we do now. They preferred to see the planet as terraqueous, a term used frequently in the seventeenth century". In the following centuries the demand for, and supply of, coastal tourism has soared, enabling this reconnection.

Accurate global figures for coastal tourism appear out of reach but there are numerous regional and national examples. Within the European Union, tourism is by far the largest employer in coastal regions, where $51 \%$ of all EU hotel bed capacity is concentrated. Moreover, coastal municipalities account for only $15 \%$ of the EU's land area and 21\% of its population (European Commission, 2017a, European Commission 2017 b). In the UK in 2015 seaside locations accounted for 39\% of holiday nights and were associated with $£ 3.84$ billion of visitor spending (Visit Britain, 2017). Coastal tourism locations have been one of the fastest growing elements of the world's largest industry for some time (Hall, 2001). For example, both the Cape Verde Islands and The Maldives have seen international visitor arrivals double in the last ten years (Trading Economics, 2018). 
Property prices are one indicator of the wider value placed on blue spaces. In developed nations across the globe, views of water significantly increase property prices (Nichols, 2014). Tourists share a willingness to pay a premium for the seaside, given accommodation prices for sea views (White et al., 2010). Approximating the worth of the coastal economy more generally is complex. The (US) National Oceanic and Atmospheric Administration (NOAA) claims that 45\% of the USA's G.D.P. was generated in counties next to bodies of water (Huffer, 2013). This reflects the economic value of trade through ports, fishing, and maritime industries but does not consider recreation and the visitor economy (National Ocean Economics program, 2009, Nichols, 2014). In 2017 an EU Blue Growth report indicated the significance and potential of the coastal economy in the region, stating it: "employs over 5 million jobs generating almost EUR 500 billion a year", and estimating the global ocean economy at EUR 1.3 trillion (European Commission, 2017a).

\subsection{The blue economy at coastal destinations}

The blue economy is increasingly recognised by governments and other bodies (European Commission, 2017a). In addition to the need for policy to address environmental pressures facing coastal areas, most obviously through 'overtourism' and climate change, exposure to this environment has increasingly been recognised as significant to human health (White et al., 2010). The evidence of a connection between coastal blue space and wellness has two broad strands. The first is economic - the allocation of time and money to visiting, or living in, certain environments reveals environmental preferences. It is assumed that blue environments are good for wellbeing because individuals are acting on/paying for their preferences. There are of course a number of assumptions and caveats within this. For an overview see Wheeler et al. (2014, pp.3-23) and Dolan and White (2007). There is abundant evidence of the 
economic value which people place on the coast. The second strand of research is psychological and offers compelling evidence regarding the potential benefits of exposure to the coast.

In the 21 st century, social and environmental psychologists now observe how exposure (or reconnection) to nature in aquatic environments offers wellness-related benefits. Seminal research by Kaplan and Kaplan (1989, p.195) suggested that restorative natural environments offer an optimal experience which can ease mental fatigue. Exposure to a 'nature' environment impacts on stress management and psychological health. Wheeler, White, Stahl-Timmins and Depledge (2012) used data from the UK's census to examine how health varied across the country and found that people are more likely to have good health the closer they live to the sea. It seems, "One of the main benefits of ocean and sea exposure may be in the way it calms the mind" (Wheeler et al., 2014, p. 11).

Ashbullby, White, Pahl and Depledge (2012) compare psychological benefits of visiting open spaces in urban areas, the countryside, and coastal regions. They find that positive feelings (for example calm, refreshment, and enjoyment) are associated with all three environments but are highest for visits to the coast followed by the countryside and then open spaces in towns and cities. Furthermore, White et al., (2010) conclude that built environments containing water are as restorative as green spaces and that environments that include water are more restorative than those without. There are however variances within this relationship between environment and wellness, not least the adoption of an appropriate state of mind (i.e. a leisure state of mind) in order to fully appreciate and benefit from these places (Gammon \& Jarratt, 2019, p.46).

Place and nature are increasingly recognised as determinants of an individuals' mental health. Nature-based interventions are increasingly common, helping to 
positively benefit mental health and wellbeing outcomes (see Natural England, 2016 for a review of these). Implications of the benefits of the natural environment are not limited to therapy but potentially apply to multiple forms of exposure to nature, not least through urban design. As urbanisation continues, urban features which may improve health, especially mental health, are of growing importance. Using a cross-sectional survey of adults and the application of geospatial techniques, Nutsford, Pearson, Kingham, and Reitsma (2016) found that higher levels of blue space visibility (rather than green space) were associated with lower psychological distress in the city of Wellington, N.Z.

In summary, although meanings associated with the coast have evolved, health and wellness have been associated with these places for centuries and current research now focuses on blue space, access to which is increasingly facilitated through coastal tourism (Gammon \& Jarratt, 2019, p.38). Tourism is vital to coastal economies, yet we live in an era of global warming. The question emerges that, if that shoreline were to dramatically change due to climate change, what would the impact be on these blue spaces and our interaction with them through leisure tourism?

\section{2) The onset of climate change and the implications for coastal tourism}

\section{1) Climate change effects on future coastal tourism}

In the coming decades, the key environmental threats to coastal locations include sealevel rise (SLR ) and increased extreme weather events resulting from human-induced climate change. Analyses of melting of the Greenland and Antarctic ice-shelves, plus modelling of national emissions contributions stemming from the 2015 Paris Climate Agreement continue to cause academics to lean towards a $3-4^{\circ} \mathrm{C}$ rise above preindustrial levels, with an expected SLR of between $50 \mathrm{~cm}$ and $2 \mathrm{~m}$, and unprecedented 
flood risks at coasts resulting from SLR and extreme weather (Nicholls et al., 2010;

DeConto, Pollard \& Gasson, 2018; Vousdukas et al., 2018). In addition, extreme weather events such as those recently seen in US coastal national park destinations where SLR and storm-surge acted synergistically will magnify coastal problems (NPS, 2018).

These physical changes will spark wide-ranging socio-economic impacts globally with both direct and indirect effects on the tourism industry. Population displacement, massive economic costs resulting from climate change and inequality of opportunity are predicted on a large scale, with greatest effects for the poorest communities in the least developed countries (LDCs), and particularly in parts of South East Asia and Africa (Nicholls et al., 2010; Rogerson, 2016). Consequently, health inequalities will also increase (McMichael, Friel, Nyong, \& Corvalan, 2008). Human ecosystem health, and ultimately planetary survival is inter-dependent on the health of biotic (organisms and ecosystems) and abiotic (climate and geomorphology) elements; for example, increases in seawater temperature will, in turn, increase the spread of waterborne diseases and change species distribution (Fleming, Leonardi, White, Medlock \& Alcock, 2018). Given recent pathogen-related concerns for tourism such as the Zika virus outbreak (Ho et al., 2017) large disruptive environmental changes have the potential to rapidly influence the global tourism economy in the future. When considering significant climatic change effects on the distribution of temperature, rainfall and other conditions across the world, the whole typology of tourism destinations could change.

\section{2) Predictions of change in tourism patterns}

Poleward shifts in tourism are a common future prediction. Climatic index predictions (see Mieczkowski, 1985) show that traditionally hot destinations such as the 
Mediterranean will become too hot for tourism, whilst cooler locations such as Canada, Scandinavia and Russia will be more desirable (Scott, Gössling, \& Hall, 2012). Studies to model global tourism flows (using influences of push-pull factors, economic growth, climate change and predicted future temperature-related destination preferences) have anticipated that tourists generated from countries nearer the poles will travel more to similar climates, when traditionally they looked for warmer climates (Hamilton, Maddison \& Tolr, 2005). Increased temperatures will drive populations towards milder climates. More temperate coastal tourism areas may benefit. Tourism in hotter regions such as South and Central Africa will move from low-lying areas to the highlands (Hamilton et al., 2005).

Modelling of SLR effects has been lacking in tourism study generally and particularly sparse in coastal tourism contexts (Scott, Simpson, \& Sim, 2012). Individually, predicted submersion and erosion impacts make coastal destinations the most affected (Nicholls et al., 2010). Disappearing beaches in the Caribbean have already negatively affected tourist demand (Scott et al., 2012b). Coastal communities and destination developers are at the forefront, being at higher risk of flooding whilst also more dependent on the preservation of natural tourism assets (Hamin \& Gurran, 2009).

Understanding the climate change-tourism relationship has become an increasing focus of research. Studies seek to understand climate change effects at coastal destinations, modelling future tourism flow, physical and economic impacts and testing potential mitigation and adaptation approaches (Simpson et al., 2008, Jones \& Phillips, 2009). Others analyse how to foster sustainable behaviour in tourists, (Kastenholz, 2004) and reduce carbon emissions from travel to avert worst-case future scenarios (McKercher, Prideaux, Cheung, \& Law, 2010). Whereas previously, demand 
predictions focused heavily on economic variables, psycho-social influences such as reaction to climate are increasingly important (Goh, 2012). Scott et al. (2012a) point to physical coastal tourism impacts including loss of low-level heritage and beaches, eventually leading to greater competition between destinations offering specific niches such as nature-based tourism. Given that favourable weather is often a key travel motivation, successful tourism development relies on optimum climates, the likely climate-driven 'poleward' movement of the most 'desirable' coastal destinations will require both tourists and destinations to be flexible (Hamilton et al., 2005).

\section{3) Mitigation and adaptation approaches to tourism policy, and the importance of the natural environment}

However climate change impacts are manifested in distributing future global flows, coastal tourism development will be subject to greater quantities of water from the sea itself and weather. Discourses on destination reaction to SLR and flooding events generally focus on mitigation, adaptation or a combination of both. Hamin \& Gurran (2009, p.239) suggest that "Mitigation strategies seek to reduce global warming over the long term, while adaptation strategies protect local communities from sudden and immediate dangers". They specify that mitigation includes densifying and diversifying land use in urban areas which leads to shorter journey times and less energy use, whilst adaptation requires more space allocated to green infrastructure (GI) for cooling and water infiltration, drainage and opening up spaces to allow water, ventilation between buildings, and biodiversity corridors.

Destination vulnerability is often discussed in terms of the propensity of destinations to mitigate or adapt to climate change effects, but is not clearly defined or agreed on, and moreover varies from physical, geographical and socioeconomic differences between destinations, and is closely tied to policy (Santos-Lacueva, Clavé \& 
Saladié, 2017). Island states are particularly vulnerable to SLR, storm surge, coastal retreat and extreme weather such as cyclones. Infrastructure and regulatory frameworks in developing countries are often ill-equipped, and differing natural characteristics are an enormous factor in the manifestation of these effects (Becken, 2005, Scott et al., 2012a).

Adaptation to submersion and erosion of beaches is crucial for coastal tourism. Scott et al., (2012b) identify beach nourishment, usually involving replacing lost sediment, as a cost-effective adaptive strategy addressing potential loss of demand, suggesting three key policies for destinations: move upland and abandon the beach; raise accommodation onto structures and manage floods, and hard and soft green infrastructural engineering. In isolation, these three strategies are inadequate and should be combined with other activities such as zoning and education. Phillips \& Jones' (2006) analysis of engineering approaches to mitigate erosion suggests that sometimes when sea defences are breached, creating salt-marsh habitats is positive for tourism and biodiversity.

Therefore, considerations of physical and natural tourism assets are central to the discussion on mitigation and adaptation. Destinations have different characteristics; one of many being their life-cycle stage. Jennings (2004) compared two UK examples of site-hardening to offset beach erosion, using the tourism life-cycle: Porlock in the Exmoor National Park, a destination in its development stage, and Sovereign Bay in Eastbourne, in a rejuvenation stage. The former could emphasise protection of natural assets rather than increasing demand, whilst the latter relied too heavily on tourism demand for its harbour, an established attraction which is protected heritage, and was therefore unable to use natural adaptive strategies. This comparison demonstrates different philosophies of varying effectiveness of valuing the tourism product: either 
placing value in built or natural heritage. Research at the Gower peninsular, Wales, (see Phillips \& Jones, 2006) found that unspoiled scenery is a valued resource for coastal destinations. Biodiversity conservation benefits reinforce this argument. However, despite the importance of preventing future habitat loss from climate change, varying socio-economic characteristics of destinations can cause barriers to coastal conservation. In the LDCs particularly, small rural communities which proliferate tourism destinations have very little capacity to cope (Rogerson, 2016).

Thus, the recurring theme surrounding mitigation and adaptation of coastal destinations is one of understanding the relationship between human socio-economic systems, and the natural environment. Their propensity to protect and enhance beaches as a tourism asset, whilst also employing varied mitigation and adaptation strategies and incorporating the arguments for the promotion of green and blue spaces for resilience or 'Nature-Based Solutions' (NBS) is a critical factor in meeting forthcoming flooding and extreme weather events. It also aligns with the argument that blue space and exposure to nature are critical to future human health. The discussion now turns to this synergy.

\section{4) Climate Change, Blue Space \& Coastal Resilience}

There are two important principles to consider:

(1) Coastal tourism and wellbeing are inextricably linked. Blue space has restorative therapeutic properties for human health, and the seaside is significant for coastal destination economies and more generally the tourism economy.

(2) Coastal tourism spaces are at the front line of climate change impact. They are under multiple threat from flooding, extreme weather and SLR. The effects could devastate economies, have wide-ranging negative socio-economic impacts and will be detrimental globally for human health. 
These two strands can be viewed both as a dichotomy and as synergistically related themes. Considering the role of the seafront for coastal tourism spaces, a common theme relates to the importance of NBS, and an assumption that coastal tourism spaces will shift poleward. Fundamentally our relationship with nature is key to coping with climate change.

The marginal nature of coastal places is, on one hand, an underlying part of their appeal, but on the other, the reason they are under threat from climate change. Industrial society creates the need to re-connect to nature and facilitates this exposure to blue space through mass tourism and leisure. At the same time industrialisation, including mass tourism, are root causes of climate change which threaten the existing shoreline to which we are drawn. Ironically perhaps, this dichotomy places the coast at the forefront of our future relationship with the natural environment.

Adaptation policies in response to unavoidable change, aim to adjust and manage tourism, reduce vulnerability and increase resilience. Whilst his is of obvious importance to coastal destinations, most publications examining adaptation tend to be non-tourism specific (Jopp, Delacy \& Mair, 2010). At the same time, most tourism strategies do not mention climate change; for example, only $21 \%$ in Australia mention it at all (Moyle et al, 2017) and Santos-Lacueva \& Velasco-Gonzalez (2018) found only surface level mention of climate change in Spain's tourism policy.

\section{5) Human resilience benefits of re-naturalising coastal destinations}

Urbanisation at coastal destinations increases impervious surfaces, reduces drainage capacity and increases run-off and leads to more pluvial flooding from excessive rain. It also takes away the visibility of natural features, the presence of which on their own demonstrate restorative properties for human health (Van den berg, Hartig \& Staats, 2007). There are a range of benefits of maintaining biodiversity (the variety of species, 
ecosystems and life itself) for human health including improved psychological wellbeing, cognitive ability, reduced blood pressure and numerous other physiological functions, commonly grouped under the umbrella term of 'ecosystem services' (Sandifer, Sutton-Grier \& Ward, 2015). On a larger scale, there is a direct link between global environmental changes and socio-economic human systems which are capable of understanding and changing, specifically by prioritising green and blue infrastructure, and integrating it with healthcare strategy (Fleming et al., 2018). We now consider how the function of nature at the coast and its integration with human systems contributes to the resilience of coastal destinations.

Coastal destinations are undergoing similar challenges to climate change resilience as those faced in many urban environments (Lanquar, p.137, 2017). They relate to urban design, with solutions based on 'hard' options (building sea defences and incorporating or retrofitting drainage into the urban fabric, see Lewis, 2018) or soft options which include a range of NBS such as increasing wetlands, increasing landscape ecology and fundamentally, letting 'nature take its course' (see Holling, 1986). Debate on the merits of engineered versus ecological resilience is not new in tourism study. For example Turner et al. (1998) identified issues with hard engineering at UK coastal destinations and the need for 'flexibility'. Successful implementation of ecologically resilient NBS requires systems thinking: considering the dynamics between soil and water systems, and their equilibrium with the wider abiotic environment including the changing climate, by enhancing resilience physically such as the resistance of soils to increased quantities of water or changing the fluxes (Keesstra et al., 2018). These dynamics and indeed the system approach to coastal resilience are also fundamentally influenced by coastal tourism activities. 
Sustainable urban development increasingly gives significant importance to the natural environment which permeates urban form (Kenworthy, 2006). However, in forming knowledge about resilience, our focus on technology and ecology often leaves out the importance of the social dimension (May \& Perry, 2017). In addition to blocking water or 'letting nature take its course', maintaining functionality in times of extreme weather or flooding events is a key feature of resilient urban design (Abdulkareem \& Elkadi, 2018). Coastal tourism systems rely on transport, food and accommodation like any other urban system. Successful future destination planning will focus more on interactions between human socio-economic systems and landform, urban morphology and topography. This adaptive combination of strengthening and maintaining human-environment systems in severe climate-related events is referred to as 'evolutionary' resilience. Davoudi, Brooks and Mehmood (2013) describe the limitations of previous focus on engineered and/or ecological resilience as being concentrated on the ability of systems to bounce back from shocks to their original states or absorb them until an equilibrium is reached. They add that evolutionary resilience also considers social dimensions and the ability of human systems to 'transform' into a more desirable state. In the context of coastal tourism, this would refer to using the impacts of climate change to result in a more positive outcome for the destination.

The emerging discussion rests on embracing benefits of NBS and in particular blue space. Davoudi et al.'s vision of evolutionary resilience includes fostering preparedness for shocks to systems, rewriting planning priorities to be more transformative and "considers climate adaptation as a continuing process, which involves social and institutional learning and transformative potentials (Davoudi et al., 2013, p.320)". There is much potential for both green and blue space to be utilised as a 
key part of the transformative process, as can be seen in the following section. In fact, in terms of human wellbeing and restorativeness alone, exposure to a combination of both is more effective than any other singular manifestation or combination of built, aquatic and 'green' environments (White et al., 2010). The question, therefore, is whether destination developers can make the coast less a 'dangerous' place and more a 'healthy' space, therefore enabling our positive relationship with the coast to continue and evolve.

\section{3) Coastal tourism policy and planning - shortfalls and good practice in relation to}

\section{climate change}

\section{1) Tourism adaptation policy gaps}

The earlier sections of this discussion identified a tendency for tourism policies and climate change policies not to talk to one another, or at least not with the focus needed for a resilient future. A study of 44 countries by the OECD (2011) found only 12 consider adaptation strategies and that two regarded them unnecessary. Only Germany and Israel implemented specific adaptation policies, but many others identified the need for raising awareness and more research although recommendations were generic. Scott et al. (2012a) suggest that the emphasis on adaptation to climate change in tourismrelated policies varies in terms of destination vulnerability and global geographical location, but overall, it is limited, and the sector is not well equipped for these challenges. On a municipal level weather-proofing, physical resilience to flooding, water quality and pollution are of high importance in environmental policy and there is an increasing emphasis on catchment-based approaches to policy which focus on river basin systems or coastlines; which suggests that individual destination tourism policies 
should cast their net wider geographically.

Balancing the needs of the environment, residents and visitors are a common policy focus. Integrated Coastal Zone Management (ICZM) approaches assume collective input and responsibility of all stakeholders for equitable and sustainable coastal areas, but academics have been sceptical of their effectiveness (Billé \& Rochette, 2015). Whilst this approach is beneficial to climatically volatile future scenarios, ICZM places key value on economic prosperity. Although stakeholders recognise the benefits of the visitor economy, residents in affected areas are understandably more worried about property and their surrounding environment (Ryan et al., 2018). Holden (2009) criticises using a market-oriented approach to assess the tourism-environment interface, suggesting that the environment is often considered as zero-cost making it vulnerable to exhaustion, leaning towards a destructive rather than a symbiotic relationship. He makes the case for rooting change in ethics and doing 'the right thing' for the environment. Through both demand and supply, tourism can foster a collective duty to nature.

Michailidou, Vlachokostas, \& Moussiopoulos, 2016 used a Multi-Criteria Decision Analysis tool to rank mitigation and adaptation policy measures. They found that stakeholders view planning and policy for controlling tourism development and redefining protected areas as favourable. In addition, success for businesses and destination developers' rests in pre-empting changes in demand caused by climate change. They frame mitigation activities as those which reduce the increase of emissions such as the uptake of clean energy, rather than efforts stop existing effects such as flooding. This mitigation of climate-change causing activity by tourism is viewed negatively by Gössling, Cohen, Higham, Peeters, \& Eijgelaar (2018) who feel that near-future tourism transport trends will favour the "business as usual approach". 
They argue that necessary sustainable changes are all based on whether "powerful players in tourism may feel compelled to act", asserting that tourism is a principal reason why $\mathrm{CO} 2$ agreements (such as the 2015 Paris agreement) will be rendered unactionable in the coming decades.

Becken's (2005) case study on Fiji highlighted that significant problems facing destinations are a lack of skills, knowledge, technology and governmental will to comprehend and act on climate change suggesting that there are major conflicts between tourism industry priorities with those of preserving the natural environment. They synergise approaches aimed at fostering sustainable behavioural change and decreasing carbon dioxide with adaptation measures including managing erosion, building new structures or moving resources, but do not discuss the transformative thinking which underpins evolutionary resilience.

\section{2) Turning coastal tourism policy around to nature and wellbeing}

It is apparent that coastal tourism policy tends to focus on adaption and mitigation which draws from wider environmental policy relating to climate change: to increase coastal resilience physically and encourage human behavioural change to minimise climate-change effects. Policy focus on blue space and wellbeing are increasingly prominent at coastal areas. We argue that this should be a greater focus of tourism development policy. Our relationship with the coast is symbiotic with the level of appreciation of the natural environment needed to make a step-change in our attitude towards mitigating climate change. It is here that transformative thinking (evolutionary resilience) and recognition of the educational value of bringing blue-space and wellbeing into the centre of the coastal tourism experience can make the most impact.

Jopp et al. (2010), Scott, de Freitas \& Matzarakis (2009) and Simpson et al. (2008) have developed modes specific to tourism adaptation. These offer an 
understanding of relevant variables but, beyond this, are not necessarily useful tools for policymakers and destinations managers, not least because the issues and levels of risk vary widely. The tourist is often missing in these models, even though they have the greatest adaptive capacity (Scott et al. 2008). Jopp et al. suggest a model reliant on two main stages: firstly, assessing the vulnerability of the destination, establishing risks and opportunities and determining the adaptive capacity; and secondly, increasing resilience, resistance and readiness using an appropriate adaptation action plan, thereby leading to decreased vulnerability.

\section{3) National and regional adaptation policies}

The destination focus of such models addresses inadequacies of those policies which tend not to focus on local or regional level adaptation and there are many national and regional differences, partly by design due to circumstances and partly due to varying levels of effectiveness of practical implementation. The development of adaption strategies is complex in practice and requires the cooperation of stakeholders and knowledge sharing (Jopp et al., 2010). In Florida, where adaptation is urgent due to its vulnerability to imminent submersion to SLR there are clear differences in political will between city and state level (Atzori \& Fyall, 2018). Rogerson (2016) notes that policy at national level on adaptation addresses concerns of fragility to climate change in South Africa but that this does not filter down to small settlements which rely on tourism but need more capacity to make suitable policies to adapt.

Integration of tourism policy scales with careful detail to individual circumstances is key to ensuring more widespread adaptation. Recently, in Samoa, the national level policy framework was applied to individual destinations with a set of criteria to build resilience into tourism development. Public and private sector collaboration was crucial, and operators had to adhere to the framework (UNWTO, 
2018a). The adaptive capacity of Samoa is dependent on shared cultural memories of past extreme events and predominantly indigenous socio-cultural networks influence collaboration (Parsons, Brown, Nalau \& Fisher, 2017). Similarly, Mycoo (2017) examined small island states in the Caribbean region and found that a combination of development approaches focused on prioritising wetlands, forests and other natural habitats at the coast and moving urban tourism inland will be of significant importance to offsetting human health problems associated with global temperature rises over $1.5^{\circ} \mathrm{C}$.

In Mexico, a series of climate change vulnerability studies focused on 20 of Mexico's popular tourist destinations were conducted between 2012 and 2016 at the request of the Ministry of Tourism. The studies involved assessment of destination climatic vulnerability and risk and facilitated workshops with local stakeholders, adopting a cost-benefit approach to evaluate various adaptation measures to be actioned by the tourism sector in each destination, including early warning systems. (UNWTO, 2018a). The information gathered was important for building up resilience of local communities and informing the nature of future tourism developments. Importantly, the Mexican studies identified areas where tourism should and should not be developed, and also guided decision-making on promoting sustainable tourism activities. For example, most development for the Mayakoba Tourism Development in Quintana Roo lies further inland than is typical for coastal mass tourism developments, which tend to use as much as the immediate coastline as possible. Much of the environmentally sensitive mangroves and dunes are purposefully left intact and act as part of the attraction of this eco-resort, which largely sits behind these environments. In addition, the development has created new aquatic and coastal habitats and boosted biodiversity in the area (UNWTO, 2018a). The examples are promising, but also recent, making it 
impossible to assess longer-term success. Nevertheless, this is a potentially useful model for future tourism and intrinsically more resilient, allowing for natural buffer zones to extreme weather. Importantly, this approach uses the environmentally rich coastal zone as a key touristic appeal and enforces strengthening the links between human and environment.

\section{4) Planning the future of coastal tourism}

The Mexican example demonstrates that destinations can be more resilient and attractive to tourists by preserving natural coastal environments, 'if' they have the flexibility and foresight to do so. However, in developed areas suffering from the 'coastal squeeze', where these areas no longer exist and where urban populations reside, the choices seem much more difficult. How will tourism, and tourists react when the effects of climate change become more visible and restrictive to this expanding industry? Although policy does not appear ready for climate change, mitigation activity at destinations will eventually supersede other drivers of tourist travel behaviour (Gössling, Scott, Hall, Ceron \& Dubois, 2012). A lot of complexities and uncertainties are associated with this and research is required to understand it more. Tourists may avoid certain destinations based on how policy-makers and destination managers cope with climate change or we might see a partial shift from coastal tourism altogether to other locations.

If the coast continues to retain its importance in tourism development, an alternative approach involves understanding the tourist experience, and how new blue spaces can be embraced. By considering ecological and perhaps more significantly evolutionary resilience, benefits include potentially increased biodiversity which is created when the erosion of beaches or submergence of coastlines occurs, such as development of wetlands, and urban spaces which are allowed to flood, creating 
recreational opportunities which are both appealing and educational. Buzinde, ManuelNavarrette \& Kerstetter (2010) argue that natural landscapes are critical for marketing tourism, but that images of pristine landscapes are often used. Their study of perceptions shows the importance of dynamism in natural landscapes to the tourist experience and nature-human interaction; tourists are now countering representations of pristine destinations by going online (using sites such as TripAdvisor) and posting more realistic reviews and pictures of wilder, less beautified locations, and therefore our coconstruction of landscape is changing. Here we see another step towards acceptance of climate change, which sits well with the transformative nature of adaptive evolutionary resilience.

Nature-based tourism is predicted to evolve firstly because of changes to the natural environment (declining coral reefs, species habitats and resources) and has already led to educational forms such as eco-tourism and disaster tourism which are climate-related (Scott et al., 2012a). McCreary et al. (2018) suggest that although nature-based and outdoor adventure tourism destinations are having to respond to adaptation with novel strategies, the higher awareness of environmental concerns increases likelihood of willingness to pay - and a higher subjective valuation of the tourists' derived experience. The solution lies in managing the physical resource by increasing stakeholder partnerships between locals and tourists at coastal destinations and emphasising their ownership of and responsibility to the natural environment.

Feedbacks within the tourist system include those between natural environment and human systems and therefore if a predominant focus on engineering sea level defences is problematic, then 'letting nature take its course' can provide a solution. Tourists' perceptions on 'managed coastal realignment' (which can include building flood defences, facilitating natural processes and creating new habitats near coasts such 
as wetlands) are bound up in identity and trust over issues such as reduced access to beaches and loss of sand; impacts such as decreasing beach attractiveness, management of the coast, enforced changes, reduction of facilities and beach amenities can all be viewed negatively depending on context (Schliephack \& Dickinson, 2017). The propensity of tourists to merely switch destinations remains more likely as has been modelled in Florida (Atzori, Fyall \& Miller, 2018) and opens arguments on whether the importance of place attachment can be superseded by the quality of actual or perceived experiences.

Understanding the tourist is key for assessing a climate-impacted future for tourism. Commentators point to preventative policies to decrease travel as being of critical importance in reducing CO2. International tourist arrivals grew by 7\% in 2017 to reach a total of 1,322 million, according to the latest UNWTO World Tourism Barometer. This strong momentum is expected to continue in 2018 at a rate of $4 \%-5 \%$ (UNWTO, 2018b). Many of these trips involve flying. Slower travel or longer stays might increase but these solutions are only workable for tourists with minimal constraints on time or movement, and the financial resources to do so. This leads to questions over inclusivity and a future which is potentially characterised by classdivided travel. Tourist apathy to not stop flying is a significant barrier to climate change prevention. Authors point to lack of in-depth knowledge of tourists to change behaviour (Hares, Dickinson \& Wiles, 2010). There is perhaps a need for more understanding of the limitations of travel to some coastal areas. Blue spaces at the coast work as an important visible educational focal point to close the attitude-behaviour gap which characterises the continuation of increased unsustainable behaviour. To develop policy which promotes these types of tourism experiences, the need for greater inclusivity and accessibility is paramount. 


\section{5) Conclusion}

In understanding a climate-affected future in coastal tourism development, it is clear that blue space will play an increasingly important role. The discussion in the earlier part of this paper demonstrates the weight of evidence underpinning the impact of blue space on health and wellbeing. We advocate a closer association between climate change, adaptation, education and natural/blue space interactions in policy to better develop coastal destinations and underpin the tourist experience. Our relationship with nature is a significant variable in our shared relationship with the coast.

Destination developers will have to undergo a systemic rethink of what assets actually are. Whilst some assets (such as coastal heritage sites) will be lost, what can be gained? Those planning urban spaces have moved from promoting 'no net loss' of biodiversity at development sites to net gain (Bull \& Brownlie, 2017). It is recommended that more integrated and place-specific policy is needed and that in particular, destination developers should consider the three forms of resilience: engineered, ecological and evolutionary and how they should be integrated at destinations.

Undoubtedly, the coast is set to change. Over time many existing coastal communities will move or be abandoned. The world has seen its first refugees as a direct result of climate change (Cooper, 2016, p.322-332). Many coastal areas are likely to focus attention on buffer zones between sea and land such as wetlands or natural floodplains, whilst some cities will continue to engineer barriers to keep waters at bay and beaches will be altered. If global tourism continues to grow in its current conditions, then perhaps exclusive man-made resorts as can be seen in Dubai today will become more prevalent: floating artificial islands for tourists or we may even see the creation of floating settlements or 'seasteads' (see The Seasteading Institute, 2019). 
Visitors accessing blue space more locally will be an especially important policy direction, and to make this happen, more aquatic areas and green spaces should be retrofitted into cities and tourist destinations. Already tidal lagoons are viewed as leisure resources and urban beaches are popular (Reichert \& Lanzer, 2015).

The search for wellness and 'blue mind' seems set to continue amongst an obesity and mental health crisis in an over-medicated society (Kim, Lee \& Sohn, 2016). Global warming will also continue, partly due to high levels of consumption and mobility. The result will be a new relationship with coastal areas for many of us; not least because the coast itself will be new. Gillis (2012 pp.7-9, p.96) summarised that industrial man had turned his back on the sea. This cannot endure. Like it or not, the coast will be brought into sharp focus in the coming years as climate change continues to pose a threat; our mindset regarding the coast will have to evolve. 'Blue cities', the new limen of 'natural' buffer zones and other spaces discussed here, suggest a potentially closer and more intimate relationship with the coast and other blue spaces. At the core of this relationship or mindset, which we tentatively describe as $\mathrm{NeO}$ terraqueous, lies an understanding of the dynamic coastal system and an ability to adapt accordingly so that we can live with our coasts. It will also rely on us respecting and valuing this environment, no longer treating it as an infinite resource to be commanded and recognising our multi-faceted reliance on it, not least in terms of health and wellbeing.

Environmental change is imminent and, above all else, marks the proposed Neoterraqueous age. Tourism and leisure will continue to facilitate access to aquatic environments and inform our opinion of them. Whether in an expanded or contracted form, this leisure and tourism will be of great social and economic importance. With this in mind, it is imperative that tourism providers start to consider their plans for the 
new coast. This is not limited to futurology, but rather short and medium-term options and responses to global warming. For this to take place, more research is needed in this area, including scenario planning. Tourism planners and decision-makers require a vision of what leisure tourism may look like in the Neo-terraqueous age.

\section{REFERENCES}

Abdulkareem, M. \& Elkadi, H. (2018). From engineering to evolutionary, an overarching approach in identifying the resilience of urban design to flood. International Journal of Disaster Risk Reduction, 28, 176-190.

Ashbullby, K., White, M., Pahl, S. \& Depledge, M. (2012). The Psychological Benefits of Visiting Natural Environments: Different Effects of the Coast, Countryside and Urban Open Space on Positive Effect. Retrieved from: https://blog.surfprevention.com/wp-content/uploads/2012/05/psychological-benefits-of-visiting-naturalenvironments.pdf

Atzori, R. \& Fyall, A. (2018). Climate change denial: vulnerability and costs for Florida's coastal destinations. Journal of Hospitality and Tourism Insights 1(2), 137149.

Atzori, R., Fyall, A. \& Miller, G., 2018. Tourist responses to climate change: Potential impacts and adaptation in Florida's coastal destinations. Tourism Management, $69,12-22$.

Becken, S. (2005). Harmonising climate change adaptation and mitigation: The case of tourist resorts in Fiji. Global environmental change, 15(4), 381-393.

Billé, R. \& Rochette, J. (2015). The Mediterranean ICZM Protocol: Paper treaty or wind of change? Ocean \& Coastal Management, 105, pp.84-91. 
Bull, J.W. \& Brownlie, S., 2017. The transition from No Net Loss to a Net Gain of biodiversity is far from trivial. Oryx, 51(1), 53-59.

Buzinde, C. N., Manuel-Navarrette, D. \& Kerstetter, D. (2010). Representations and adaptation to climate change. Annals of Tourism Research 37(3), 581-603.

Cooper, A. (2016) Images from a warming planet Global Warming Images Publishing, Ambleside, Cumbria.

Corbin, A. (1995). The Lure of the Sea. Blackwell: London.

Davoudi, S., Brooks, E. \& Mehmood, A. (2013). Evolutionary resilience and strategies for climate adaptation. Planning Practice \& Research, 28(3), 307-322.

DeConto, R., Pollard, D. \& Gasson, E. (2018). Implications of the Paris Climate Agreement for future sea-level rise from Antarctica. In EGU General Assembly Conference Abstracts, 20, 18291

Dolan, P. \& White, M. (2007). How can measures of subjective wellbeing be used to inform public policy? Perspectives on Psychological Science, 2(1). 71-85.

European Commission (2017a), Report on the Blue Growth Strategy: Towards more sustainable growth and jobs in the blue economy. Retrieved from European Commission: https://ec.europa.eu/maritimeaffairs/sites/maritimeaffairs/files/swd-2017128_en.pdf

European Commission (2017b). Integrated Marine Policy - Coastal and Marine Tourism. Retrieved from European Commission: https://ec.europa.eu/maritimeaffairs/policy/coastal_tourism_en.pdf

Fleming, L. E., Leonardi, G., White, M., Medlock. \& Alcock, I. (2018). Beyond climate change and health: Integrating broader environmental change and natural environments for public health protection and promotion in the UK. Atmosphere, 9(7), 245. 
Gammon, S. \& Jarratt, D. (2019) Keeping leisure in mind: the intervening role of leisure in the blue space - health nexus. In R. Foley, R. Kearns, T. Kistemann \& B. Wheeler (Eds.) Blue Space, Health and Wellbeing: Hydrophilia Unbounded. (pp. 3852) Routledge: Abingdon.

Gillis, J. (2012). The Human Shore: Seacoasts in History. Chicago: Chicago University Press.

Goh, C. (2012). Exploring impact of climate on tourism demand. Annals of Tourism Research, 39(4), 1859-1883.

Gössling, S., Scott, D., Hall, C. M., Ceron, J. P., \& Dubois, G. (2012). Consumer behaviour and demand response of tourists to climate change. Annals of Tourism Research, 39(1), 36-58.

Gössling, S., Cohen, S., Higham, J., Peeters, P., \& Eijgelaar, E. (2018). Desirable transport futures. Transportation Research Part D: Transport and Environment, 61. 301-309.

Hall, M. C. (2001) Trends in Ocean and Coastal Tourism: the end of the last frontier. Ocean \& Coastal Management, 44, (9-10), 601-618

Hamin, E. M. \& Gurran, N. (2009). Urban form and climate change: Balancing adaptation and mitigation in the US and Australia. Habitat international, 33(3) 238-245.

Hamilton, J.M., Maddison, D.J. and Tol, R.S., 2005. Effects of climate change on international tourism. Climate research, 29(3), pp.245-254.

Hansen, R., Frantzeskaki, N., McPhearson, T., Rall, E., Kabisch, N., Kaczorowska, A., ... \& Pauleit, S. (2015). The uptake of the ecosystem services concept in planning discourses of European and American cities. Ecosystem Services, 12, 228246. 
Hares, A., Dickinson, J. \& Wiles, K. (2010). Climate change and the air travel decisions of UK tourists. Journal of transport geography 18(3). 466-473.

Ho, L.-L., Tsai, Y-H., Lee, W-P., Liao, S-T., Wu, L-G. \& Wu, Y-C. (2017). Taiwan's Travel and Border Health Measures in Response to Zika. Health security 15(2), 185-191.

Holden, A. (2009). The environment-tourism nexus: Influence of Market Ethics. Annals of Tourism Research 36(3), 373-389.

Holling, C. S. (1986). The resilience of terrestrial ecosystems: local surprise and global change. Sustainable development of the biosphere 14, 292-317.

Huffer, H. (2013), The Economic Value of Resilient Coastal Communities, NOAA report Retrieved from: http://www.ppi.noaa.gov/wpcontent/uploads/EconomicValueofResilientCoastalCommunities.pdf Jarratt, D. \& Gammon, S. (2016). 'We had the most wonderful times': seaside nostalgia at a British resort. Tourism, Recreation Research, 41(2) 123-133

Jennings, S. (2004). Coastal tourism and shoreline management. Annals of Tourism Research 31(4) 899-922.

Jones, A. L. \& Phillips, M. R. (2009). Disappearing destinations: Climate change and future challenges for coastal tourism, Cabi.

Jopp, R., Delacy, T. and Mair, J. (2010). Developing a framework for regional destination adaptation to climate change. Current Issues in Tourism, 13(6), 591-605.

Kaplan, R. \& Kaplan S. (1989). The experience of nature. New York: Cambridge University Press.

Kastenholz, E. (2004). Management of Demand as a Tool in Sustainable Tourist Destination Development. Journal of Sustainable Tourism, 12(5), 388-408. 
Keesstra, S., Nunes, J., Novara, A., Finger, D., Avelar, D., Kalantari, Z., \& Cerdà, A. (2018). The superior effect of nature based solutions in land management for enhancing ecosystem services. Science of the Total Environment, 610, 997-1009.

Kenworthy, J. R. (2006). The eco-city: ten key transport and planning dimensions for sustainable city development. Environment and urbanization, 18(1), 6785.

Kim JH, Lee C, Sohn W. (2016) Urban Natural Environments, Obesity, and Health-Related Quality of Life among Hispanic Children Living in Inner-City Neighborhoods. International Journal of Environmental Research and Public Health. 13(1) 121.

Lanquar, Robert. (2017) Urban Coastal Tourism and Climate Change: Indicators for a Mediterranean Prospective. In Tourism in the City. (137-145) Springer: Cham. Lewis, R. (2018). Considerations for Engineered Resilience from Examples of Resilient Systems. In Disciplinary Convergence in Systems Engineering Research, (4156). Springer: Cham.

May, T., \& Perry, B. (2017). Knowledge for just urban sustainability. Local Environment, 22(sup1), 23-35.

McKercher, B., Prideaux, B., Cheung, C., \& Law, R. (2010). Achieving voluntary reductions in the carbon footprint of tourism and climate change. Journal of sustainable tourism, 18(3), 297-317.

McCreary, A., Fatoric, S., Seekamp, E., Smith, J.W., Kanazawa, M. \& Davenport, M.A., (2018). The Influences of Place Meanings and Risk Perceptions on Visitors' Willingness to Pay for Climate Change Adaptation Planning in a Nature-Based Tourism Destination. Journal of Park \& Recreation Administration, 36(2). 
McMichael, A. J., Friel, S., Nyong, A., \& Corvalan, C. (2008). Global environmental change and health: impacts, inequalities, and the health sector. British Medical Journal, 336(7637), 191-194.

Michailidou, A. V., Vlachokostas, C. \& Moussiopoulos, N. (2016). Interactions between climate change and the tourism sector: Multiple-criteria decision analysis to assess mitigation and adaptation options in tourism areas. Tourism Management, 55, 112.

Mieczkowski, Z. (1985). The tourism climatic index: a method of evaluating world climates for tourism. Canadian Geographer 29(3), 220-233.

Moyle, C. J., Moyle, B. D., Chai, A., Hales, R., Banhalmi-Zakar, Z. \& Bec, A. Have Australia's tourism strategies incorporated climate change? Journal of Sustainable Tourism 26(5), 703-721.

Mycoo, M.A., (2018). Beyond 1.5 C: vulnerabilities and adaptation strategies for Caribbean Small Island developing states. Regional environmental change, 18(8), 2341-2353.

National Ocean Economics Program (2009), State of the U.S. Ocean and Coastal Economies, Retrieved from: https://www.miis.edu/media/view/8901/original/NOEP_Book_FINAL.pdf

Natural England (2016). A review of nature-based interventions for mental health care. Retrieved from Natural England: http://publications.naturalengland.org.uk/publication/4513819616346112? category=127 020

Nichols (2014) Blue Mind: The Surprising Science That Shows How Being Near, In, On, or Under Water Can Make You Happier, Healthier, More Connected, and Better at What You Do. Retrieved from: https://www.littlebrown.com/?s=blue+mind 
Nicholls, R. J., Marinova, N., Lowe, J. A., Brown, S., Vellinga, P., De Gusmao, D., \& Tol, R. S. (2011). Sea-level rise and its possible impacts given a 'beyond 4 C world' in the twenty-first century. Philosophical Transactions of the Royal Society of London A: Mathematical, Physical and Engineering Sciences, 369(1934), 161-181. NPS (2018) Sea Level Rise and Storm Surge Projections for the National Park Service. Retrieved from NPS: https://www.nps.gov/subjects/climatechange/upload/2018-NPS-Sea-Level-ChangeStorm-Surge-Report-508Compliant.pdf

Nutsford, D., Pearson, A., Kingham, S. \& Reitsma, F. (2013) Residential exposure to visible blue space (but not green space) associated with lower psychological distress in a capital city, Health \& Place 39, 70-78.

OECD (2011) Climate Change and Tourism Policy in OECD Countries Retrieved from OECD: https://www1.oecd.org/industry/climate-change-and-tourismpolicy-in-oecd-countries-9789264119598-en.htm

Parsons, M., Brown, C., Nalau, J. and Fisher, K., (2018). Assessing adaptive capacity and adaptation: insights from Samoan tourism operators. Climate and Development, 10(7), pp.644-663.

Phillips, M. R. \& Jones, A. L. (2006). Erosion and tourism infrastructure in the coastal zone: Problems, consequences and management. Tourism Management, 27(3), 517-524.

Reichert, L. \& Lanzer, R.M., 2015. Sustainable tourism development in the coastal lagoons of Osorio County, Rio Grande do Sul, Brazil: characteristics and specificities of these natural resources. TURyDES: Revista Turismo y Desarrollo local, $8(18)$. 
Rogerson, C. M. (2016). Climate change, tourism and local economic development in South Africa. Local Economy 31(1-2) 322-331.

Ryan, A., Gorddard, R., Abel, N., Leitch, A. M., Alexander, K. S., \& Wise, R. M. (2011). Perceptions of Sea- Level Rise Risk and the Assessment of Managed Retreat Policy: Results from an Exploratory Community Survey in Australia CSIRO: Climate Adaptation National Research Flagship 54

Sandifer, P. A., Sutton-Grier, A. E., \& Ward, B. P. (2015). Exploring connections among nature, biodiversity, ecosystem services, and human health and well-being: Opportunities to enhance health and biodiversity conservation. Ecosystem Services, 12, 1-15.

Santos-Lacueva, R., Clavé, S.A. and Saladié, Ò. (2017). The vulnerability of coastal tourism destinations to climate change: The usefulness of policy analysis. Sustainability, 9(11), 2062.

Santos-Lacueva, R. and Velasco González, M. (2018). Policy coherence between tourism and climate policies: the case of Spain and the Autonomous Community of Catalonia. Journal of Sustainable Tourism, 26(10), 1708-1727.

Schliephack, J. \& Dickinson, J. E. (2017). Tourists' representations of coastal managed realignment as a climate change adaptation strategy. Tourism Management, 59, 182-192.

Scott, D., de Freitas, C., \& Matzarakis, A. (2009). Adaptation in the tourism and recreation sector. In Biometeorology for adaptation to climate variability and change, (171-194) Springer: Dordrecht.

Scott, D., Amelung, B., Becken, S., Ceron, J. P., Dubois, G., Gössling, S., ... \& Simpson, M. (2008). Climate change and tourism: Responding to global challenges. World Tourism Organization, Madrid, 230. 1-38 
Scott, D., Gössling, S., \& Hall, C. M. (2012). International tourism and climate change. Wiley Interdisciplinary Reviews: Climate Change, 3(3), 213-232.

Scott, D., Simpson, M. C., \& Sim, R. (2012). The vulnerability of Caribbean coastal tourism to scenarios of climate change related sea level rise. Journal of Sustainable Tourism, 20(6), 883-898.

Simpson, M. C., Gössling, S., Scott, D., Hall, C. M., \& Gladin, E. (2008). Climate change adaptation and mitigation in the tourism sector: frameworks, tools and practices. Climate change adaptation and mitigation in the tourism sector: frameworks, tools and practices.

The Seasteading Institute (2019) Reimagining Civilization with Floating Cities Retrieved from The Seasteading Institute: https://www.seasteading.org/

Turner, R. K., Lorenzoni, I., Beaumont, N., Bateman, I. J., Langford, I. H., \& McDonald, A. L. (1998). Coastal management for sustainable development: analysing environmental and socio-economic changes on the UK coast. Geographical Journal, 269-281

Trading Economics (2018) Maldives - International tourism, number of arrivals. Retrieved from Trading Economics: https://tradingeconomics.com/maldives/international-tourism-number-of-arrivals-wbdata.html

UNWTO (2013) Sustainable marine tourism: Expert Group Meeting on Oceans, Seas and Sustainable Development: Implementation and follow-up to Rio+20, 18-19 April 2013, UN Headquarters, New York

UNWTO (2018) Tourism for Development Volume II: Good Practices Retrieved from UNTWO: https://www.e-unwto.org/doi/pdf/10.18111/9789284419746 
UNWTO (2018) Barometer Retrieved from UNTWO:

http://media.unwto.org/press-release/2018-01-15/2017-international-tourism-resultshighest-seven-years)

Van den Berg, A. E., Hartig, T., \& Staats, H. (2007). Preference for nature in urbanized societies: Stress, restoration, and the pursuit of sustainability. Journal of social issues, 63(1), 79-96.

Visit Britain (2017). The GB Tourist. Retrieved from Visit Britain: https://www.visitbritain.org/sites/default/files/vb-corporate/DocumentsLibrary/documents/England-documents/gb_tourist_report_2015.pdf

Vousdoukas, M. I., Bouziotas, D., Giardino, A., Bouwer, L. M., Mentaschi, L., Voukouvalas, E., \& Feyen, L. (2018). Understanding epistemic uncertainty in largescale coastal flood risk assessment for present and future climates. Natural Hazards \& Earth System Sciences, 18(8). 2127-2142

Wheeler, B. W., White, M., Stahl-Timmins, W., \& Depledge, M. H. (2012). Does living by the coast improve health and wellbeing? Health \& place, 18(5), 1198 1201.

Wheeler, B., White, M., Fleming, L., Taylor, T., Harvey, A. \& Depledge, M. (2014) Influences of the Oceans on Human Health \& Well Being. In Bowen, R., Depledge, M., Cinnamon, C. \& Fleming, L. (eds), Oceans and Human Health, Oxford: Wiley.

White, M., Smith, A., Humphryes, K., Pahl, S. Snelling, D. \& Depledge, M. (2010). Blue Space: The importance of water for preference, affect, and restorativeness ratings of natural and built scenes, Journal of Environmental Psychology, 30(4), 482493. 